\title{
Colonization by $S$. Aureus increases the EASI and the number of appointments by patients with atopic dermatitis: cohort with 93 patients
}

\author{
Colonização por $S$. aureus eleva o EASI e o número de consultas dos pacientes \\ com dermatite atópica: coorte com 93 pacientes
}

\author{
Caroline Lipnharski ${ }^{1}$ \\ Giancarlo Bessa ${ }^{4}$
}

\author{
Pedro Alves d'Azevedo ${ }^{2}$ \\ Renan Rangel Bonamigo
}

Vanessa Petry Quinto ${ }^{3}$

DOI: $h t t p: / / d x . d o i . o r g / 10.1590 / a b d 1806-4841.20132046$

\begin{abstract}
BACKGROUND: Atopic dermatitis leads to epidermal barrier dysfunction and bacteria colonization. The relationship of the last factor with the severity of the disease and the frequency of exacerbation is not fully known. OBJECTIVES: Verify the severity of the atopic dermatitis and the number of appointments generated by dermatosis, comparing patients colonized with patients not colonized by $S$. aureus. Verify the frequency of colonization by methicillin resistant Staphylococcus aureus acquired in the community. METHODS: Cohort study with a 12 months follow-up, in a sample of patients from Porto Alegre, RS public network. Cultures in active injuries and nasal cavities were carried out as well as methicillin sensitivity tests to $S$. aureus. The severity of atopic dermatitis was defined by Eczema Area and Severity Index (EASI). RESULTS: We included 93 patients, $43 \%$ female and $56 \%$ male, 26 colonized by S. aureus in the nasal orifices, 56 in the skin damage. The mean of initial Eczema Area and Severity Index was 5.5 and final 3.9. The initial Eczema Area and Severity Index of patients colonized by $S$. aureus in the skin and nasal cavity was larger than the number of patients without colonization( $\mathrm{p}<0.05)$. During the period of one year, in average, there were six appointments/patient. There was linear correlation between the number of appointments during one year and the inicial Eczema Area and Severity Index $(r=0,78)$. There were no patients with methicillin resistant Staphylococcus aureus acquired in the community. CONCLUSION: There is a relevant influence of staphylococcal colonization on the severity of atopic dermatitis and the number of appointments required by its exacerbation. Methicillin resistance among those affected by $S$. aureus does not seem to be an emergent problem, in this Brazilian sample. Keywords: Dermatitis, atopic; Injury severity score; Severity of illness index; Staphylococcus aureus
\end{abstract}

Resumo: FunDAMENTOS: A Dermatite Atópica cursa com alteração da barreira cutânea e colonização bacteriana; a relação deste último fator com a gravidade da doença e a frequência das exacerbações não é completamente conhecida. OBJETIVOS: Verificar a gravidade da Dermatite Atópica e o número de consultas ocasionadas pela dermatose, comparando pacientes colonizados e não colonizados pelo Staphylococcus aureus (S. aureus). Verificar a frequência de colonização por Staphylococcus aureus meticilina resistentes da comunidade. MÉrodos: Estudo de coorte, com 12 meses de acompanhamento, em amostra de pacientes da rede pública de Porto Alegre, RS. Realizaram-se culturais de lesões ativas e fossas nasais e testes de sensibilidade à meticilina para o S. aureus. A gravidade da Dermatite Atópica foi estabelecida pelo Eczema Area and Severity Index. RESULTADOS: Incluídos 93 pacientes, $43 \%$ femininos e $56 \%$ masculinos, 26 colonizados por S. aureus na região nasal, 56 em lesão cutânea. A média do Eczema Area and Severity inicial foi 5,5 e a do final 3,9. O Eczema Area and Severity Index inicial dos pacientes colonizados por S. aureus em lesão cutânea e nas fossas nasais foi maior que o dos pacientes não colonizados ( $\mathrm{p}<$ 0,05). Em um ano, seis consultas por paciente ocorreram, em média. Houve correlação linear entre o número de consultas em um ano e o Eczema Area and Severity Index inicial $(r=0,78)$. Não houve encontro de Staphylococcus aureus meticilina resistentes da comunidade. CONCLUSÃO: Há uma importante influência da colonização estafilocócica na gravidade da Dermatite Atópica e no número de consultas por sua exacerbação. A resistência à meticilina entre os S. aureus não parece constituir-se como problema emergente, nesta amostra brasileira.

Palavras-chave: Dermatite atópica; Escala de gravidade do ferimento; Índice de gravidade de doença; Staphylococcus aureus

Received on 05.08.2012.

Approved by the Advisory Board and accepted for publication on 06.09.2012.

* Study carried out at the Sanitary Dermatology Service (Ambulatório de Dermatologia Sanitária) of the state of Rio Grande do Sul and Dermatology Service of the Federal University of Health Sciences (Universidade Federal de Ciências da Saúde de Porto Alegre - UFCSPA), Porto Alegre - Porto Alegre (RS), Brazil.

Financial Support: None

Conflict of Interest: None.

MD. Resident in Dermatology at the Universidade de Ciências da Saúde de Porto Alegre - Porto Alegre (RS), Brazil.

PhD in Microbiology and Adjunct Professor of the Department of Basic Health Sciences of the Universidade de Ciências da Saúde de Porto Alegre - Porto Alegre (RS), Brazil.

Dermatologist, Master's degree in Pathology at the Universidade de Ciências da Saúde de Porto Alegre - Porto Alegre (RS), Brazil.

Dermatologist, Master's degree at the Universidade de Ciências da Saúde de Porto Alegre - Porto Alegre (RS), Brazil.

Dermatologist, PhD in Dermatology and Head of the Dermatology Service at the Universidade de Ciências da Saúde de Porto Alegre - Porto Alegre (RS), Brazil.

(O2013 by Anais Brasileiros de Dermatologia

An Bras Dermatol. 2013;88(4):518-21. 


\section{INTRODUCTION}

Atopic Dermatitis (AD) is characterized as a chronic inflammatory skin disease related to genetic changes in the proteins that support the epidermal barrier and associated with asthma and rhinitis. ${ }^{1}$

In general, $\mathrm{AD}$ affects approximately $5-20 \%$ of children and $1-3 \%$ of adults and in spite of a very low risk of death, it has a high impact in terms of morbidity and on the quality of life of patients., ${ }^{2,3}$

AD patients are at increased risk of developing bacterial colonization, especially staphylococcal. ${ }^{4,5}$ The Staphylococcus aureus (S. aureus) can be isolated in skin lesions in $76-100 \%$ of cases and may be involved in the exacerbation of $\mathrm{AD}^{6.10}$

The effect attributed to colonization leads to attempts to suppress bacterial growth in the management of AD. On the other hand, due to documented cutaneous infection susceptibility, AD patients require more frequent use of topical and systemic antibiotics, which can lead to the development of greater microbial resistance in this population and the resulting colonization by new microorganisms, such as MRSA (methicillin resistant Staphylococcus aureus). ${ }^{11}$

Nevertheless, there have not been studies in Brazil demonstrating the association between staphylococcal colonization in AD patients and a higher frequency and/or an increased severity of exacerbations.

The present study was developed because of the known variability of bacterial colonization in patients with $\mathrm{AD}$, recognizing the importance of having more knowledge about microbiological epidemiology, which may assist in the care of these patients.

Our objectives were to verify, in patients with $\mathrm{AD}$, the prevalence of staphylococcal colonization and CA-MRSA (methicillin resistant Staphylococcus aureus in the community), the severity of dermatosis in patients colonized by $S$. aureus and the effects of this colonization on the number of consultations over a year of monitoring.

\section{MATERIALS AND METHODS}

The study was approved by the Research Ethics Committee of the Federal University of Health Sciences of Porto Alegre and the School of Public Health of Rio Grande do Sul, Brazil.

It is a prospective cohort study of one year duration for each patient. During the years 2010 and 2011, 93 patients diagnosed with AD who attended the Dermatology Service at the Federal University of Health Sciences of Porto Alegre and the Dermatology Health Clinic of the State of Rio Grande do Sul were monitored.

The study included AD patients with the diagnosis made in accordance with Hanifin's and Rajka's criteria. ${ }^{12}$ The study excluded patients with criteria for hospital acquired MRSA, and those who were using systemic antibiotics at the time or period of one month prior to consultation, and/or using topical antibiotics at the time or within 15 days prior to the consultation and also patients colonized by other microorganisms. All of the study participants, or their legal guardians, signed an informed consent term.

Samples were obtained by collecting a swab of $\mathrm{AD}$ skin lesion and of uninfected nasal cavity. The severity score used was the EASI (Eczema Area and Severity Index), validated internationally. ${ }^{12}$

Procedures for microbiological identification were carried out by phenotypic tests for characterization of Staphylococcus sp (Gram stain, colony morphology, fermentation of mannitol salt agar); by further tests (catalase, coagulase, DNAse); by antimicrobial susceptibility tests (Difco and D-diffusion test) and genotypic tests (PCR for detection of gene mec A, multiplex PCR to determine the type of SCCmec, PCR detection lukF gene, encoding the PVL polymorphism analysis of chromosomal DNA).

Each patient was followed for 12 months regarding the number of new consultations due to the exacerbation of AD. The EASI was applied at the first visit and again after one year. The median of the cases was found for comparison purposes.

To measure the significance of the results, the statistical test of Bartlett's was used.

\section{RESULTS}

The variables and the demographic characteristics relating to the study sample are shown in table 1.

Ninety-three patients were followed, with approximately $45.2 \%$ female and $54.8 \%$ male. In terms of age, the average was 2.5 years old; about $13 \%$ were infants (0-21 months), $72 \%$ were preschool to school (2-11 years), $11.6 \%$ were teenagers and young adults (12-29 years) and $1.1 \%$ were adults over 30 years.

The initial EASI of the patients showed a median of 5.5 (with minimum 0.4 and maximum 40.5), and a final median EASI 3.9 (minimum of zero and a maximum of 56.8).

Regarding the number of consultations after 12 months, a median of 6 was shown, with a minimum of three visits and a maximum of 17 appointments.

In relation to the colonization by $S$. aureus, among the 93 patients, 26 and 56 were colonized, respectively, in skin lesions (SAL) and in the nasal passages (SAN). In total, 64 patients $(68.8 \%)$ were colonized, considering the nasal cavity and / or skin. CA-MRSA was not detected in the samples.

Colonized patients were compared with those not colonized at the initial severity (EASI). 
Graph 1 shows that SAL patients have an EASI higher when compared to those who were not colonized, the result being statistically significant $(\mathrm{p}=$ 0.0212).

Graph 2 shows the comparison of SAN patients in relation to non colonized $(p=0.0059)$.

Graph 3 shows the linear correlation (r) between the number of consultations in one year and the EASI, where the correlation coefficient is relevant, $r=0.78$. $(0.5 \leq r<0.8)$.

\section{DISCUSSION}

$\mathrm{AD}$ is among the most common chronic inflammatory skin dermatoses in childhood. Thus, in accordance with several studies from different countries, this study carried out in southern Brazil showed a higher frequency of dermatoses in children (11 years) compared to other age groups, with an average age of 2.5 years.

Skin colonization with $S$. aureus among patients with $\mathrm{AD}$ is common, particularly in skin lesions and in the nasal passages. Our study also found a significant prevalence of staphylococcal colonization.

The results showed a direct association between the initial severity (EASI) and the presence of nasal bacteria $(p=0.0059)$. This finding confirms the evi- dence already described in other publications. A cohort from 2009 showed that Dutch children with positive nasal colonization by $S$. aureus at 6 months of age not only had a higher risk of developing $\mathrm{AD}$, but also an increased risk of moderate to severe $\mathrm{AD}$, compared to non carriers. ${ }^{13}$

Likewise, in this study, patients with positive $S$. aureus in $\mathrm{AD}$ lesions were more severely affected than those without the bacteria, the results being statistically significant $(p=0.021)$.

Some studies have found an increasing proportion of MRSA in individuals with AD, including that of Nishijima et al, who documented an increase from $34.2 \%$ to $41.5 \%$ in a period of three years. Another study, from 2008, comprising 54 patients with AD from a hospital in Philadelphia (USA), showed a high colonization by $S$. aureus ( $80 \%$ ) but isolated MRSA in only seven $(16 \%)^{5}$

In our research with this sample from southern Brazil a growth of CA-MRSA was not noticed in cultures, demonstrating a particular microbiological and epidemiological overview.

The present study showed a strong linear correlation $(r=0.78)$ between the EASI and the initial number of consultations within a year, as shown in graph 3 , with a clear trend to increased frequency of consulta-

TABLE 1: Factors evaluated in patients with Atopic Dermatitis, $n=93$

\begin{tabular}{ll}
\hline Factors & $\mathbf{N = 9 3}$ \\
\hline Age & 2.5 years (mean) \\
Sex & $51(54.8 \%) / 42(45.2 \%)$ \\
Colonization by S. aureus in the skin damage & 26 patients $(\%)$ \\
Nasal colonization by S. aureus & 56 patients $(\%)$ \\
Initial EASI & 5.5 (median) \\
Final EASI & 3.9 (median) \\
Number of appointments during 12 months & 6 (median)
\end{tabular}

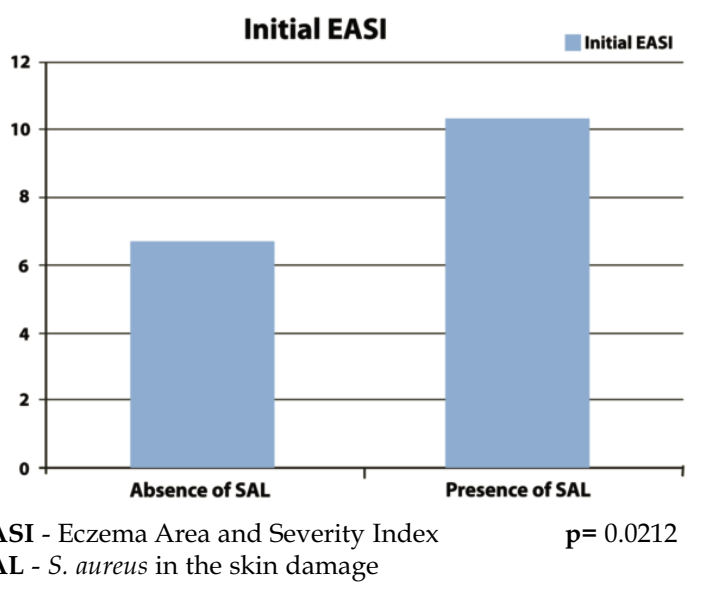

GRAPH 1: Initial EASI and colonization by S. aureus in the skin damage

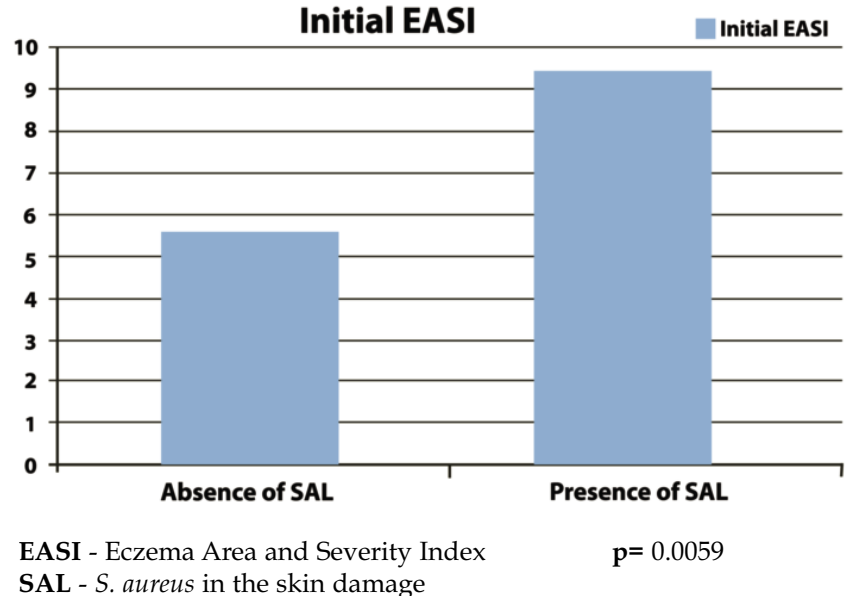

SAL - S. aureus in the skin damage

GrAPH 2: Initial EASI and colonization by S. aureus in the nasal cavities 


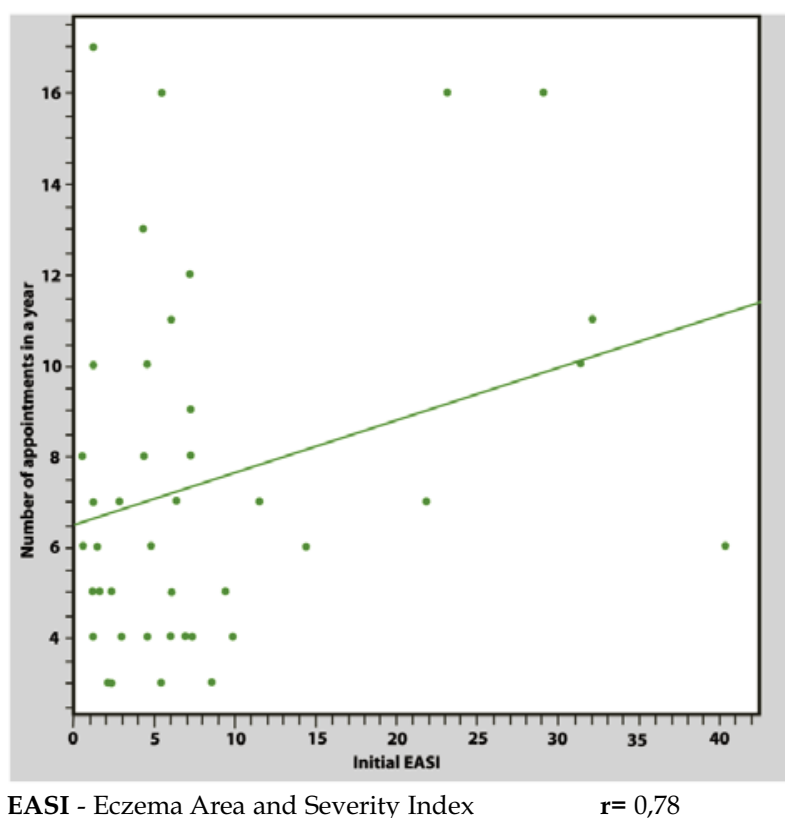

GRAPH 3: Correlation between EASI and the number of appointments tions linked to the higher initial EASI; the most severe cases tend to return more times in one year, compared with less severe ones.

\section{CONCLUSION}

This sample of southern Brazil showed $68.8 \%$ of colonization by $\mathrm{S}$. aureus in patients with $\mathrm{AD}$; there was greater severity of $\mathrm{AD}$ and a higher number of consultations due to exacerbation of the disease among those colonized by $S$. aureus.

CA-MRSA colonization was not a major problem in this sample from southern Brazil, during the study period.

\section{REFERENCES}

1. Cork MJ, Robinson DA, Vasilopoulos Y, Ferguson A, Moustafa M, MacGowan A, et al. New perspectives on epidermal barrier dysfunction in atopic dermatitis: geneenvironment interactions. J Allergy Clin Immunol. 2006;118:3-21.

2. Laughter D, Istvan JA, Tofte SJ, Hanifin JM. The prevalence of atopic dermatitis in Oregon schoolchildren. J Am Acad Dermatol. 2000;43:649-55.

3. Rothe, MJ, Grant-Kels JM. Atopic dermatitis: an update. J Am Acad Dermatol. 1996;35:1-13

4. Hanifin JM, Cooper KD, Ho VC, Kang S, Krafchik BR, Margolis DJ, et al. Guidelines of care for atopic dermatitis, developed in accordance with the American Academy of Dermatology (AAD)/American Academy of Dermatology Association "Administrative Regulations for Evidence-Based Clinical Practice Guidelines". J Am Acad Dermatol. 2004;50:391-404.

5. Suh L, Coffin S, Leckerman KH, Gelfand JM, Honig PJ, Yan AC. Methicillin-Resistant Sthaphylococcus aureus Colonization in Children with Atopic Dermatitis. Pediatr Dermatol. 2008;25:528-34.

6. Huang JT, Abrams M, Tlougan B, Rademaker A, Paller AS. Treatment of Staphylococcus aureus colonization in atopic dermatitis decreases disease severity. Pediatrics. 2009;123:e808-14.

7. Leyden JJ, Marples RR, Kligman AM. Staphylococcus aureus in the lesions of atopic dermatitis. Br J Dermatol. 1974:90:525-30.

8. Higaki S, Morohasi M, Yamagishi T, Hasegawa Y. Comparative study of staphylococci from the skin of atopic dermatitis patients and from healthy subjects. Int $\mathrm{J}$ Dermatol. 1999;38:265-9.

9. Abeck D, Mempel M. Staphylococcus aureus colonization in atopic dermatitis and its therapeutic implications. Br J Dermatol. 1998;139:S13-6.
10. Krakowski, AC, Eichenfield LF, Dohil MA. Management of atopic dermatitis in the pediatric population. Pediatrics. 2008;122:812-24.

11. Hoeger PH. Antimicrobial susceptibility of skin-colonizing $S$ aureus strains in children with atopic dermatitis. Pediatr Allergy Immunol. 2004;15:474-7.

12. Hanifin JM, Thurston M, Omoto M, Cherill R, Tofte SJ, Graeber M. The eczema area and severity index (EASI): assessment of reliability in atopic dermatitis. Exp Dermatol. 2001:10:11-8.

13. Lebon A, Labout JA, Verbrugh HA, Jaddoe VW, Hofman A, van Wamel WJ, et al. Role of Staphylococcus aureus nasal colonization in atopic dermatitis in infants: the Generation R Study. Arch Pediatr Adolesc Med. 2009;163:745-9.

How to cite this article: Lipnharski C, d'Azevedo PA, Quinto VP, Bessa G, Bonamigo RR. Colonization by S. Aureus increases the EASI and the number of appointments by patients with atopic dermatitis: cohort with 93 patients. An Bras Dermatol. 2013;88(4):518-21. 